\title{
Outdoor Motor Play: Analysis, Speculations, Research Paths
}

Andrea Ceciliani $^{* 1}$ And Alessandro Bortolotti ${ }^{2}$

$\approx$ In our rapidly changing contemporary society, it has become apparent that children spend significantly less time playing outdoors than their parents did. Therefore, considerable attention must be paid by professionals to engage this challenge, especially within early educational contexts. The goal of this study was to first explore the continual drive of play in educational growth and, second, the ways in which children play outdoors at school, in order to reap the developmental benefits of outdoor play in a supportive context, where such fundamental activity is not only allowed, but also supported. The results of this study reinforce existing research in this area, highlighting the findings of children's physical play behaviour and its frequency, also in connection with the use of tools and toys; further findings highlight teacher's attitudes and suggest several options for early childhood professionals to foster children's enjoyment of outdoor play. Finally, the study results have implications for future opportunities in the planning of active spontaneous-play.

Keywords: Outdoor motor play; Development; Motor behaviour; Observation 


\section{Gibalne igre na prostem: analiza, predvidevanja, raziskovalne poti}

Andrea Ceciliani ${ }^{\star}$ in Alessandro Bortolotti

V V spreminjajoči se sodobni družbi postaja očitno, da se otroci na prostem igrajo precej manj časa, kot so se njihovi starši. To za strokovnjake v vzgoji in izobraževanju predstavlja velik izziv, predvsem v zgodnjem obdobju šolanja. Prispevek sprva razišče pomembno vlogo igre pri učnem razvoju, raziskati pa želimo tudi oblike gibalnih iger na prostem v šoli, $\mathrm{s}$ katerimi lahko $\mathrm{v}$ spodbudnem okolju pripomoremo $\mathrm{k}$ razvojnemu vidiku igranja na prostem, ki je v šoli ne samo dovoljeno, ampak tudi zaželeno. Izsledki o obnašanju otrok med gibalnimi igrami in pogostostjo igranja (tudi z uporabo različnih orodij in igrač) potrjujejo že obstoječe izsledke raziskav na tem področju. Na podlagi ugotovitev je predlaganih več mogočih oblik dela, s katerim bi strokovnjaki na področju zgodnjega otroštva pri otrocih vzgajali veselje do iger na prostem. Ne nazadnje izsledki raziskave pripomorejo $\mathrm{k}$ načrtovanju spontanega igranja otrok v prihodnje.

Ključne besede: igre na prostem, razvoj, motorično obnašanje, opazovanje 


\section{Introduction: Classifications of Play}

Our research subject concerns education through motor play; since it constitutes a wide area of study, we must limit our analysis to remain focussed. To clearly define our epistemological framework, it is useful to start by giving some fundamental references to the concept of play in general; we will then investigate motor play in particular.

From the conceptual viewpoint, it is not easy to define play - an idea shared also by other scholars (Bateson, 1956); to borrow Bateson's metaphor, it is as volatile as smoke; even though it might appear to be a contradictory statement, we could assert that it is precisely its ineffability, or its indeterminacy, that better defines our subject. Therefore, the enunciation of the idea of play cannot be too limited; on the contrary, it, in turn, implies that we play with it. In any case, the impermeability of play to its 'ultimate' understanding - its ineffability - represents both its weakness and its strength; in order to fully understand this uncanny concept, it is useful to retrieve the idea of 'paradox', that is a situation that, at the same time, can be understood as a given reality and as its opposite: a situation that Bateson (1972) clearly described. Another example suggested by Vygotskij (1979) will help us to better clarify this point: if a child plays and pretends to ride a broomstick as if it were a horse, jumping up and down (with the broomstick between his legs) so to mime the animal pace (and even its cry), his action is somehow 'real' because he 'really acts' as if he were a horse; and yet, at the same time, his action is also imaginary, because in that very moment he pretends that the broom is a horse, while all others know it is only a broom (straddled by a child who is playing with it). We could define this experience as being simultaneously real and false, depending on the viewpoint we apply to it: in other words, it is a true paradox. ${ }^{3}$

It is necessary to remember that our studies take into consideration real and historical activities, which are easy to be observed and also to be catalogued (even though always in a determined and partial way) as they help to answer our first question: to define play. By using Di Pietro's schematic (2003), which is based precisely on the paradoxical nature of play, we can assert that the various forms of play can be grouped into eight dimensions situated along a circular schematic (Figure 1), and diametrically opposed, which exemplify in a paradigmatic way the two-faced nature of play. In our opinion, the great value of this schematic is in the fact that,

3 We want to underline that it is because of the idea of 'paradox' that play can constantly reinvent so-called 'reality', it can modify all defined categories and help us to open new ones; it is not by chance that many innovative works in the fields of art, design or science, show many points of contact with play (Winnicott, 1971). We believe that it is mainly for these reasons that play has been seen as the human experience which that than any other has contributed to establish human culture to the point that homo sapiens is called also homo ludens, in addition to homo faber (Huizinga, 1949). 
even though it constitutes an interpretation (i.e. an abstraction), it nevertheless has been conceived upon a tangible understanding of the reality of play on the basis of how we know it through its historically determined manifestation; therefore, it constitutes the result of a legitimate operation of classification similar to the one carried out, for instance, by Callois (1958) to which, not by chance, it is indebted.

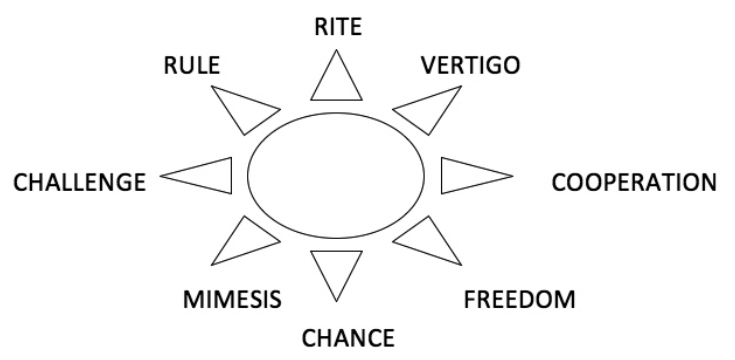

Figure 1. The Opposing Dimensions of Play.

However, a fundamental difference between the phenomenon of play in general and motor play exists, i.e. the role of motion or, as we define it, of the 'motor behaviours' (a concept that we will retrieve later on in this essay). Essentially, what defines the concept of motor play in a precise way is the fact that it depends upon the player's movements, the way in which they are performed, so much so that it is not irrelevant to evaluate both modes and efficacy of all body movements to appreciate play in itself. Rather, such an evaluation represents the element that makes a difference for the result of motor play, thereby contributing to determine the preferences people give to the various activities, as they usually choose to commit to those passages in which they perform well so to increase their sense of 'selfefficacy' (Bandura, 1977), and abandon those in which they are not successful. It is essential to observe, in fact, that in order to be successful, it is not sufficient to ideally elaborate an efficacious action plan; it is also essential to put it into practice through a series of body movements that to reach the pre-set goal in a concrete way. Context conditions and self-image also play a fundamental role on these processes (Shilder, 1935).

With the phrase 'motor behaviours', we intend to call attention to the complexity of 'motor play', considering that a player must always pay attention to the following elements while playing: the paradoxical experience of play, the context conditions, and, last but not least, the result of his own action (which depends mostly upon the subjective psycho-physical condition). It is not by chance that motor education has been defined as the 'science of the motor behaviours of decision' (Parlebas, 1997) that involves all aspects of the human being; the individual is 
globally involved, even though the outlines of the involved elements can be clearly limited. Among them, we can recall the following: biological, because the movement develops organic functions; cognitive, with reference to Piaget (1945) we can easily state that logic, spatial-temporal categories, etc., develop through motor experience; social and communicative, as we usually play in groups, even as little children, so much so that we are somehow 'forced' to relate and communicate with others; affective and expressive, since the reason for movement always involve an emotion, something that literally means 'move from' and implies the adoption of postures and attitudes which are 'expressive'; decisional, as play always forces to take decisions, and sport and motor play strongly emphasise this condition with time constraint in a way which stimulate autonomy, assumption of responsibility, and the intuitive and inferential capability. From the perspective of pedagogical speculations, the latter theme represents the most distinct and less acknowledged contribution to the educational potentialities that can be ascribed to motor activity.

\section{Outdoor Physical Play}

Although current WHO recommendations suggest a minimum of 60 min of physical activity per day, ${ }^{4}$ it seems that only half of preschool-aged children achieved this: i.e. nearly half of preschool-aged children do not engage in sufficient physical activity (Tucker, 2008). Therefore, effective interventions that promote and foster physical activity in children are necessary for meeting the recommended guidelines. It could be argued that among pre-primary school-aged children, active and unstructured play taking place out-of-doors during children's free times may be the foremost provider to extensive bodily activity, rather than structured activities (Bailey et al., 1994). Pellegrini and Smith (1998), analysing the developmental functions of physical play, defined it as a playful context combined with a dimension of physical vigour; they suggest that forms of physical activity play primarily serve immediate developmental functions. Furthermore, when playing outdoors, children grow emotionally and intellectually by enjoying their environment, participating in dramatic play, developing initiative, and acquiring an understanding of basic concrete concepts, such as investigating the property of objects and of how to accomplish a simple task. Such vigorous play activities can, in addition, enhance the growth of the child's expected development, for example, by helping improve appetite, strength and bodily growth (Pica, 2003) and increasing learning abilities (Clements, 2004). Therefore, a greater understanding of active free-play and the individual, social and environmental influences on these behaviours may be critical for the promotion of children's physical

4 http://www.who.int/dietphysicalactivity/factsheet_young_people/en/index.html 
activity and growth at school (Burdette \& Whitaker, 2005). Essentially, the spaces in which children engage in most of their active free-play, and their influences on the play activities are largely unknown and require further investigations (Veitch et al., 2006). However, our findings, based both on quantitative and qualitative data, provide insights into contextual influences on children's behaviours during scholastic outdoor spontaneous play, specifically the use of little tools and toys and teacher's attitudes towards them. We believe that our results support several suggestions to early childhood professionals in order to promote children's' enjoyment of meaningful outdoor play.

\section{The Setting of the Empirical Work}

Our work is based on two main pillars: a solid knowledge of literature and a series of observations in the field. The literature is rich with references to the educational relevance of play (Farné, 2005; Hurwitz, 2002; Smith, 1995; Tsao, 2002) considered as a support to children's potentialities for development, something that must be emphasised in relation to the dimensions of personality.

First of all, we have to ask some questions: why observe play and, in particular, motor play? Then, what do we observe of play? We can answer the first question by referring to two complementary dimensions: there are no doubts that it is in particular during the early childhood (as clearly pointed out by all schools of psychomotor tradition (Le Camus, 1980)) that to children's play represents a fundamental means for their psychophysical relation with the environment; therefore (and this is the 'other side of the coin' of the educational relation), adults, especially those who are responsible for the children's educational care, must and should be able to allow, observe and valorise play (Kern \& Wakeford, 2007; Pellegrini \& Smith, 1998).

\begin{tabular}{|l|l|}
\hline \multicolumn{2}{|l|}{ MOTOR PATTERNS CHECK-LISTS } \\
\hline 1 & HANDLING \\
\hline 2 & RUNNING \\
\hline 3 & JUMPING, HOPPING, JUMPING DOWN \\
\hline 4 & THROWING \\
\hline 5 & CLIMBING \\
\hline 6 & SLIDING \\
\hline 7 & SWINGING \\
\hline 8 & KICKING \\
\hline 9 & FIGHTING - ROUGH/TUMBLE \\
\hline 10 & PULLING - PUSHING \\
\hline 11 & CYCLING \\
\hline 12 & CARRYING \\
\hline
\end{tabular}

Figure 2. Motor Patterns Check-List. 
The second question, regarding what to observe of play, requires a more articulated answer, because the theme is much broader and, therefore, it requires additional explanations; furthermore, it relates to our research, so much so that we must introduce it in order to better understand how it connects to what we are presenting here. In fact, our investigation is part of broader research on 'Educational Cares' carried out by scholars at our Department of Educational Sciences at the University of Bologna (Contini \& Manini, 2007). For us, educational care means underlining all aspects recalled this far, and, in particular, re-enhancing the healthy relevance of motor play so to suggest a truly pedagogical valorisation of it. A previous survey carried out through questionnaires and interviews distributed and collected in infant schools (Bortolotti, 1997) indicated a fundamental element: the fact that we could notice a massive gap between some theoretical principles (such as 'motor activity is fundamental for learning processes') and what was, in fact, the reality of practical teaching, as the latter often privileged other more 'formalised' activities to the point that we had to face statements such as: 'we notice, though, that there is not much time to let the children play'. In other words, there was a clear contradiction between saying and doing.

Therefore, some questions emerged which we must attempt to answer: how do teachers act 'in practice' when children play motor games? Which are the considerations beyond their actions? Which are the spaces and the materials dedicated to the so called 'free play'? Also, what are children's favourite games? How and for how long do they move? In order to answer such questions, we have chosen to carry out an investigation based mostly on the observation of the way children play outdoors in infant schools.

\section{Observing Outdoor Physical Play}

For us, it proved fundamental to establish a method of direct observation that could be as systematic and as 'reasonable' as possible, i.e. very rigorous from the methodological viewpoint; a method that could answer our questions through efficacious and appropriate techniques of investigations. In brief, we decided what to observe only situations that were standard in the daily contexts, attempting to be a discrete presence and not interfere with what was happening; to focus our attention on the 'outdoor' contexts, as we can say that 'indoor, spontaneous play is suffocated', to borrow an eloquent expression used by one

5 We must acknowledge that, as former athletes and as teachers at the Faculty of Physical Education, we are not indifferent the object of study; instead, it is part of a 'world view' that involves not only educational, but also existential styles and values that make us truly passionate for our field of study. This is not a neutral element of our research to the extent that we deemed appropriate to assert it. 
of the teachers involved in our research; to use video recordings, always carried out in pairs (it was extremely beneficial that both of us had a video camera so to be able to follow as many subjects as possible moving in broad areas), as they enabled performing a quantitative evaluation of motor activities in various settings; to analyse our videos through checklists, so as to further developed our study of both the strictly motor (Figure 2) and the socio-motor perspectives, the latter being approached through Rubin POS (2001); to delimitate the age limits on which we wanted to concentrate for our research.

Concerning this last point, we must distinguish between two phases of our work: in phase one, we concentrated our research on children aged either three or five years (two ages that correspond to the accomplishment of a school cycle (nursery first, and then infant school)) with the goal of pointing out relevant elements through the comparison of the different general situations. In the second phase, we took into consideration the intermediate age (i.e. we studied children aged four) in view of a longitudinal continuation of our research, mainly focused on the relationship between children play with tools and toys, and their motor behaviours. Our research involved eight schools: three infant schools and five nursery schools, about 170 children, and 22 teachers; we had 18 observational sittings and collected 24 hours of videos.

Given the above, we consider our work as heterogeneous from various view-points: quantitative and qualitative; eco-ethological. We do not consider this to be a limit, but instead it constitutes a richness. On balance, this is typical of play, as it involves all aspects of a human being, considered as a whole: we tend to make divisions in an analytical mode, by carrying out continuous abstractions and readings of 'meaning'. If the analysis succeeds in providing clear results of many factors, it cannot but be an enrichment of the research.

\section{'Conditions' and Rhapsody of Spontaneous Outdoor Motor Play}

In the research project that we have planned (Ceciliani \& Bortolotti, 2007a), we have acted in a way to indicate some useful categories or plans of analysis that can be taken as points of reference for both teachers and researchers, as we think they could be used not only as tools for the evaluation of educational research, but also to improve teachers' didactic and pedagogical tasks. Essentially, it was essential to define, inside the so-called 'free play', the conditions of the action in their twofold meaning: positive, because, to some extent, they can in fact be defined as the ensemble of those elements that enable to carry out the activity, and which constitute a setting made of times, spaces, tools, and of 
educational attentions; but we must also recall that the same elements restrain the activity of play, that they condition it in a negative way because they offer guidance that is strictly dependent upon rules (i.e. limitations) determined by the educators (teachers, assistants, etc.) (Farné, 2005). The overall analysis of the various situations we have observed conveys the impression that we should not talk about 'free play' inside schools, but we should use a more correct definition: spontaneous play; even though freedom of play is assured, at least at the level of initial impulse (so that spontaneity is assured), it nevertheless seems to be extremely limited in the choices that are conditioned by the context to the point that we could here use the concept of probation.

In our opinion, a good example of a mode in which spontaneous play takes place could be associated to the concept of 'rhapsody', which recalls a particular rhythm of play based on launching and retrieving some themes of play. Moving from the idea that in play there is always something that escapes, observation should monitor the impromptu aspects and the novelties, without being restrained to too clearly limited categories; by doing so, it would be possible to recognise and valorise whatever new and unexpected behaviour emerges, given the intrinsic force that these situations have, and which emerges inside such a complex phenomenon that we could consider to be chaotic. Moving from such a need, we have elaborated the concept of 'play rhapsody', a term to designate a type of phenomenon characterised by irregular rhythms, sometimes slow, other times frantic, characterised by continuous repeated movements, by constantly recurring leitmotifs with infinite variations, which combine plans and categories disrespectfully; a phenomenon which can be rendered at its best only through the 'visual' description of games (see here below the story of 'The Little She-Zombie Girl').

\section{The Little She-Zombie Girl}

There are six little girls making a circle, the 'director' of the game is placed in the middle, while a girl is in front of the others and walks keeping her arms outstretched and her legs stiff, like a zombie. The group runs to the opposite side of the garden to hide behind the bushes and play other games, the Zombie runs and tries to find them, but, once she has reached the group, the same scene is repeated. This play activity, alternated with other games, takes place during the whole period of observation, to the extent that a high percentage of running performed by the females is surveyed. At the end, the Zombie, who has not succeeded to enter the group continuously escaping from her, attempts to get closer to her mates punching and kicking. At this, the others go away and she stops running after them. 


\section{The Psychomotor Behaviour (Figures 3 and 4 )}

The observations on the videos gathered during our first survey enabled us to evaluate the motor behaviours most used by children aged 3 and 5 (last year of nursery school and of infant school).

Our data showed the presence of all motor behaviours in children aged 5 and the absence of some motor behaviours in children aged 3: to jump, to throw, to kick, to rough and tumble (Figures 3 and 4). Most likely, the stage of psychomotor development limits some motor behaviours that require a higher level of development: for instance, to kick, to jump and to throw are often conditioned by the process of lateralisation, ${ }^{6}$ which is still premature at that age.

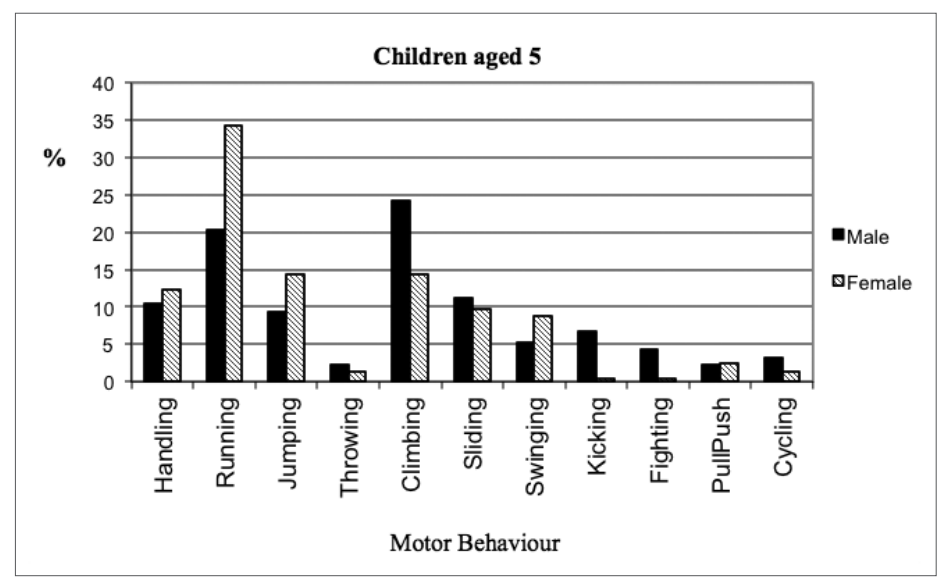

Figure 3. Motor Behaviours of 5 Years Old Children.

Instead, rough-and-tumble play presupposes a certain development of social skills (Scott \& Panksepp, 2003; Smith et al., 2004): a little child does not understand why, while playing, he can be thrown down, pushed or pulled by another child. Some motor behaviours are shared by children aged both 3 and 5 (to run; to handle; to climb; to slide) and appear to be preparatory activities (basic behaviours) in comparison with more developed motor behaviours.

6 Lateralisation is the process which, moving from the dominant genetic hemisphere, leads to the distribution of different functions in various body segments. For instance, in right-handed people, the main functions are distributed as follows: support/push in the inferior left limb; leap/ attack in the inferior right limb; the dominant hand is the right one; the sub-dominant hand is the left one; the dominant eye is the right one; the sub-dominant eye is the left one. The chest acquires balancing functions in relation to the correct distribution of the above stated functions, as it accompanies the coordinated actions of both upper and lower limbs with appropriate movements during the motor behaviours. 


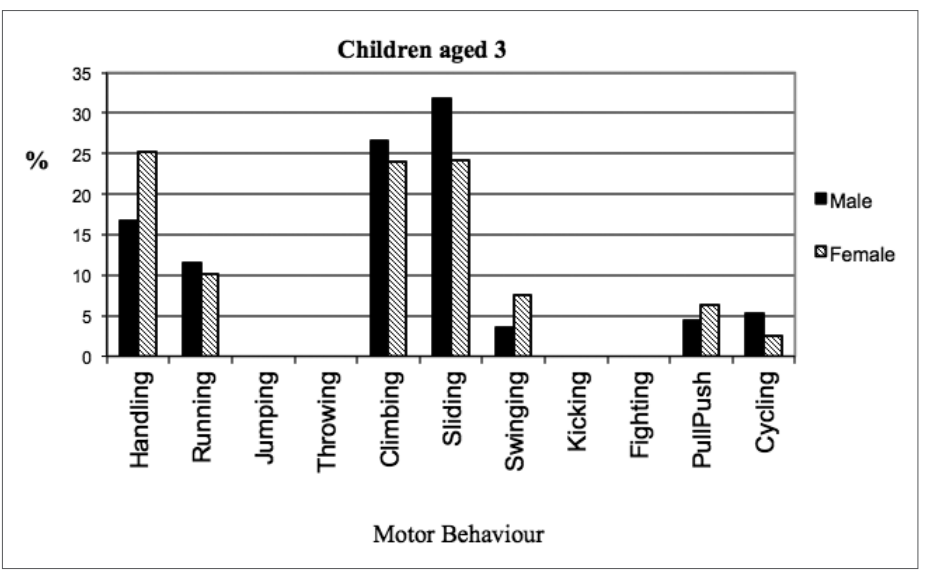

Figure 4. Motor Behaviours of 3 Years Old Children.

Climbing. In infancy school, unlike in primary school (Ceciliani, 20o8), males tend to climb in a divergent way both on codified tools (castle, rope ladders, wooden ladders, slide) and on trees. During this manifestation of 'task orientation' (Spray et al., 2001) and self-efficacy perception (Bandura, 1977, 2001), they accomplished extremely difficult motor tasks: climbing along the sides of the wooden castle; climbing up the slide; upside-down rocking in popliteal hold ${ }^{7}$ on branches and tools; climbing of large trees. In contrast, females only climbed the codified tools (castle, rope ladders, wooden ladders) and always in the appropriate mode.

In nursery schools, the act of climbing often relates to the 'jumping on' various elements located in their environment (big tools, fixed toys, tables, benches), rather than to the real act of climbing. Males and females showed a remarkably balanced gender percentage, whereas in the percent of climbing behaviours that we observed males showed a higher percent of accomplishment (Figure 3). No difference was detected concerning the modes of climbing, as they were all convergent with the standard use of the various tools and equipment (always and only the artificial codified ones).

Handling. Handling is an activity which children of both ages share, even though the percent is higher at the nursery school (Figures 3 and 4 ). The interest of little children for the fine motor activities limits their motor behaviours as it requires a higher concentration and precision connected to the technique of how to use toys, little tools and other devices. This should explain, at least

7 This is a technical term used to indicate a person suspended on an upright/support (pole, branch or other) through the hold of the inferior limbs, wrapped around the support, accomplished through the back side of the knee (poplite). 
in part, why little children are more static than older ones. Generally speaking, in the presence of toys and little tools children prefer to concentrate on how to handle them; only after having satisfied this need do they open up to other freer and associative games (climbing, riding tricycles, climbing castles or rope dome-shaped toys). As a result, it is evident that the educational care in relation to the manifestation of spontaneous play can also be characterised by the way the teaching setting is organised: the presence or the absence of little tools conditions the modes of play in a very powerful way, as well as the quantity and quality of the related motor behaviours.

Running. In contrast, in the infant school running is by far the most liberating motor behaviour. In fact, this movement is not always linked to specific activities or games; instead, it often represents a moment of motor relief, a 'play of exercise' (Piaget, 1972). Among children aged 5, females were committed to a free interpretation (vent) or semi-structured (running-up games), whereas males ran also when playing codified games (soccer, basketball). This explains how codified games are already rooted in infancy culture, even though with rules and modes more similar to the paidia play than to the ludus play (Caillois, 1995); in contrast, females are less conditioned by this type of activity.

In the case of children at the infant school, we did not notice genderbased differences, and running was less frequent: it was produced through a sketch of the real motor scheme, which was generally used to move from one point to the other of the courtyard as a play of exercise (Piaget, 1972), or induced by teachers during some guided activities. Children aged 3 seemed to compensate the lack of motor behaviour, such as running through the use of tools such as slides, as they show greater interest in these tools than older children.

Jumping and hopping. Jumping, hopping and jumping down ${ }^{8}$ are activities that are carried out more by males than by females. Generally speaking, females carried out these motor behaviours in performance-like activities related to individual dances, but also to little choreographies carried out in pairs or small groups (3-4 little girls). As previously stated, males used jumping as a competitive expression: jumping farther or higher. As observed in the case of climbing, males tended to challenge themselves in the continuous search for activities pushed to the limits of their possibilities.

Throwing and kicking. In comparison with males, females did not show motor behaviours related to kicking and throwing. As previously acknowledged,

8 The jump downwards is a strategy to control the flight balance and it is essentially practised by young children. It consists in reaching an elevated surface (the kerb, a bench, or similar) and jump to the ground. This behaviour enables the child to experience the emotion of flying, to hover oneself for a moment without any ties in the context of a safe descent and touch of the ground. 
males have linked the first two motor behaviours to codified sport activities (soccer and basketball) and, only once, to free play (a group of three males launching a ball). Females did not show any interest for this type of activity. Rather, what is strange is the disappearing of throwing as a sort of practicing activity, i.e. as an activity used to show one's own ability by throwing all sorts of things (pebbles, sticks, cones, or other), to prove both strength (to throw far away) or precision (to throw to hit the target). These behaviours were not registered also among children aged 3 , both males and females.

Rough-and-Tumble Play Fighting. Concerning rough and tumble play (Scott, 2003; Smith, 2004), this game concerned mostly little boys who carried out an extraordinarily rich rhapsody: from hand-to-hand fighting (pushes and real wrestling), to pair tournaments ('sword duels'), to tug-of-war (two teams grouping 6-7 children). ${ }^{9}$ Females, just like all children aged 3, never played these games.

In brief, even though they privileged some motor behaviours upon others, children aged 5 showed a greater play rhapsody as they performed the full range of basic motor behaviours. In contrast, given the same environmental conditions, children aged 3 showed a more limited play rhapsody, as it did not include all basic motor behaviours, but only those that were more functional to their actual growth. Generally speaking, to sum up gender differences in free play behaviours, we can assert a different dynamism between males and females, especially in the kindergarten; this is related to a higher need of males to challenge themselves in comparison to their personal limits in motor behaviours, a need which did not emerge in a meaningful way among females.

\section{Presence/Absence of Toys and Tools (Figures 5 and 6)}

Our second survey concerned children aged 4 attending two infant schools. We observed them in three different situations: free play; the presence of toys and little tools; the absence of toys and little tools. Non-parametric tests enabled us to observe the homogeneity of the groups in the two schools $(\mathrm{p}<.05)$ under the three different conditions (Mann-Whitney); the relevance of the eventual differences in the same group under the three different situations (Wilcoxon); possible gender differences (Mann-Whitney).

Concerning the three situations we observed, the analysis of the data did not show any relevance ( $\mathrm{p}>.05$ ) between Condition 1 and Conditions 2 and 3, both in terms of general data and in terms of the analysis of females and males only.

9 This is the activity that engaged the highest number of children, whereas all other activities we observed the playing group counted - a part from pairs - three or four children at the most. 
What emerges from the latter observation is the presence of a series of dominant behaviours (running, carrying, handling, climbing) in comparison with a series of accessory behaviours (jumping, throwing, sliding, swinging, rough/tumble). These behaviours (Figure 5) show the higher percentages of realisation in the 'with tools condition', as well as in the 'without tool' condition.

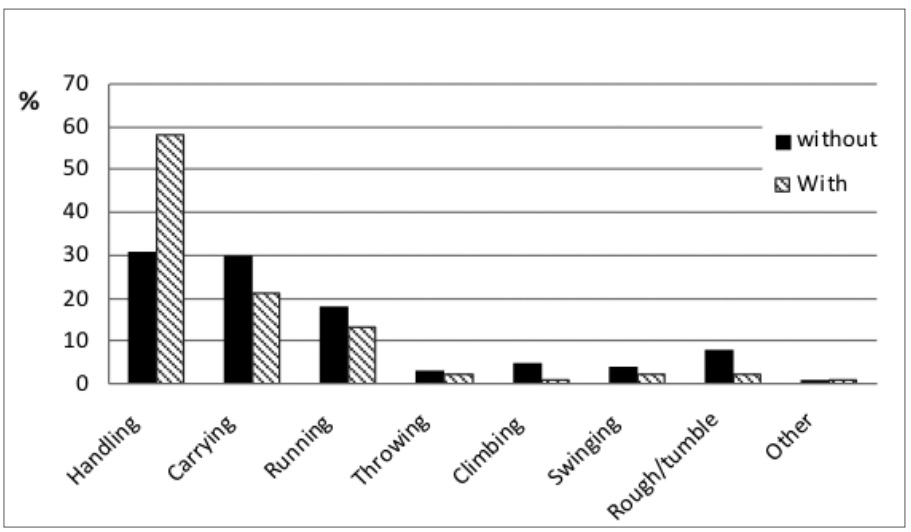

Figure 5. Motor Behaviours of 4 Years Old Chidren with and without Tools and Toys.

Therefore, we can state that some psycho-motor behaviours are dominant in the motor development of children of this age. This is even more valid if we take into consideration the fact that all observations were carried out outdoors, in large spaces equipped with big tools. Even in this condition, children showed the fundamental need for running, handling and climbing and, only in an accessory form, the need for throwing, swinging, sliding, roughing and tumbling).

Obviously, the passage from a situation without tools to a situation with tools increases the manifestation of handling behaviour in a relevant way, thereby decreasing the manifestation of others behaviours (Figure 5). Dynamism diminishes, but that does not affect the previously noticed relation between dominant and accessory activities. Therefore, notwithstanding the presence of tools/toys, children tended to carry out a certain range of motor actions (i.e. those that we considered as dominant) with a higher frequency than the range of accessory actions. Gender differences are not relevant in the observed situations (Figure 6), even though we could observe psycho-motor aspects related more to male behaviours (such as rough and tumble) or to female behaviours (such as all activities related to the act of 'swinging'). 


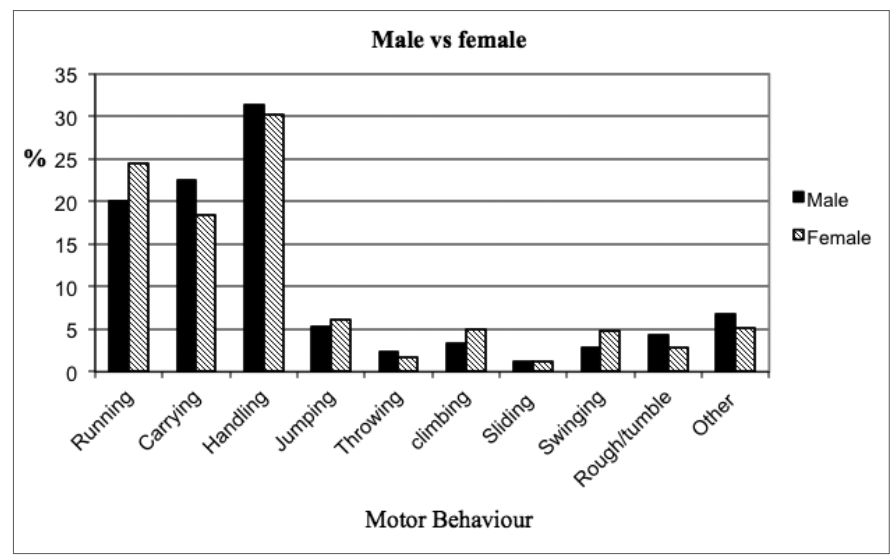

Figure 6. Motor Behaviours of Different Gender Children.

\section{Socio-Motor Behaviour (Figures 7 - 12)}

The first survey (Bortolotti \& Ceciliani, 2007b; Ceciliani et al., 2009), with reference to Rubin's POS (2001), showed (Figures 7, 8) the following: the presence of all four typologies of play in children aged 5; the absence of competitive play in children aged 3, with a prevalence of solitary and parallel play. Gender differences were present in children aged 5 and showed a higher male propensity for solitary and competitive play. These results are in line with other previous studies (Parlebas, 1986).

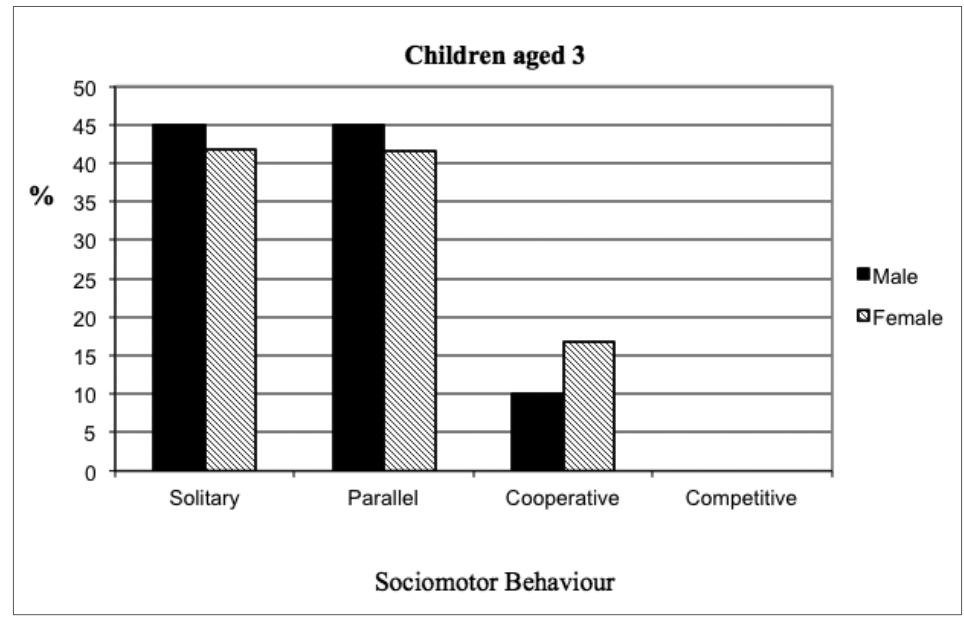

Figure 7. Social Play Behaviours of 3 Years Old Children. 


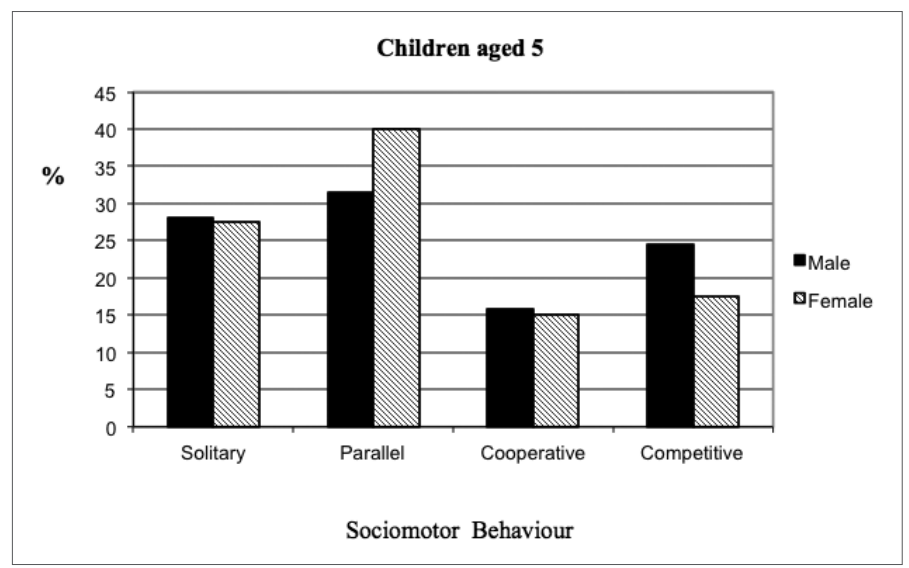

Figure 8. Social Play Behaviour of 5 Years Old Children.

The observations of the three proposed conditions carried out in our second survey (Ceciliani \& Bortolotti, 2009), confirmed the rate of the three main socio-motor behaviours: solitary play, parallel play, group play (Rubin, 2001).

Within the relation between these three behaviours and the explorative behaviour (Figure 9), it is possible to notice a constant trend of group play, a constant decrease (even though not terribly relevant $(\mathrm{p}>.05)$ of solitary play, and a drastic reduction of parallel play in the condition with toys. It is interesting to notice that in the three mentioned conditions, from free play to play with tools, the explorative play increases in a constant way as it shows relevant progress $(\mathrm{p}<.05)$ from condition 1 to condition 3 . To summarise, it seems that the presence of tools better qualifies group play by means of explorative activities, which (in the case of the children we studied) became symbolic games (the search for dinosaur bones; the search for some treasures, etc.).

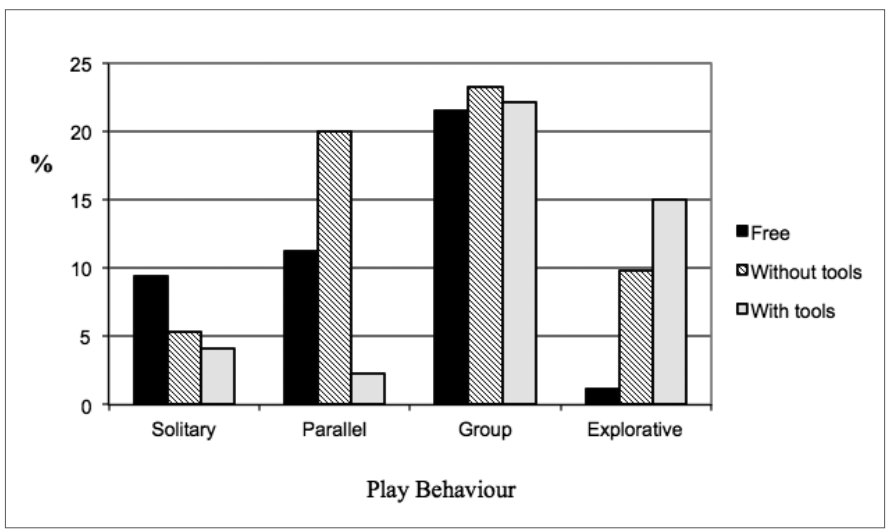

Figure 9. Play Behaviours of Chidren with and without Tools and Toys. 
In Figure 10, we can observe some compelling cross-readings of the way the three typologies of play occur. Actually, whereas functional play tends to decrease in the passage from the condition of free play to the condition presence/absence of tools/toys, the expressions of constructive and dramatic play increases. In particular, it is possible to notice that dramatic play is widely present both in the presence and absence of toys, whereas the constructive play is dependent on toys and tools. We could state that play behaviour is fundamentally linked to parallel and group play. In addition, the presence of small tools seems to facilitate group play and to stimulate explorative (Figure 9), dramatic and explorative (Figure 10) play.

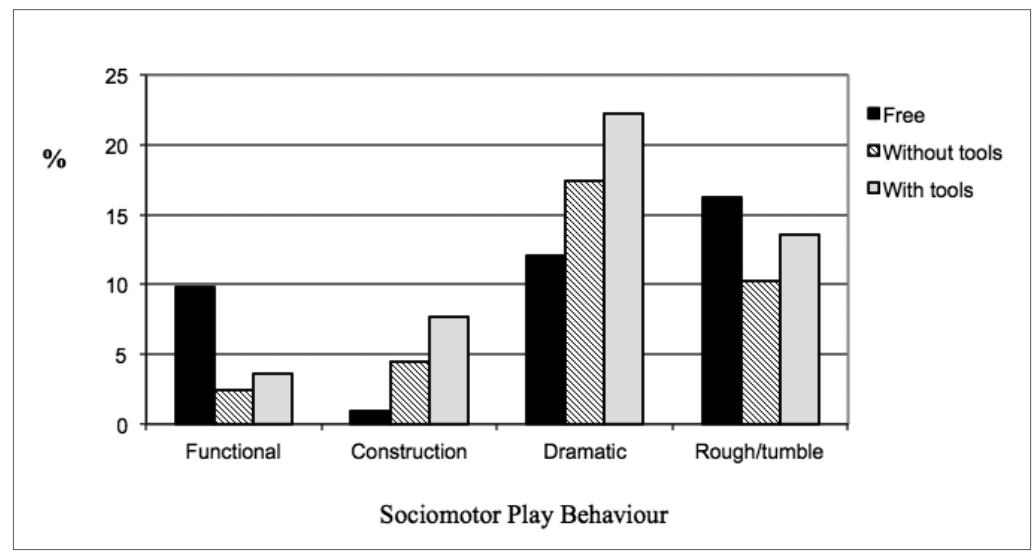

Figure 1o. Sociomotor Play Behaviours of Chidren with and without Tools and Toys.

In the condition of free play, the most relevant gender differences $(\mathrm{p}<.05)$ refer to an increased practice of rough-and-tumble play for males (Smith et al., 2004; Scott, 2003; Pellegrini, 1998), and an increased practice of dramatic play for females.

Such a difference (see Figures 11 and 12) is not relevant for the two other conditions of play. 


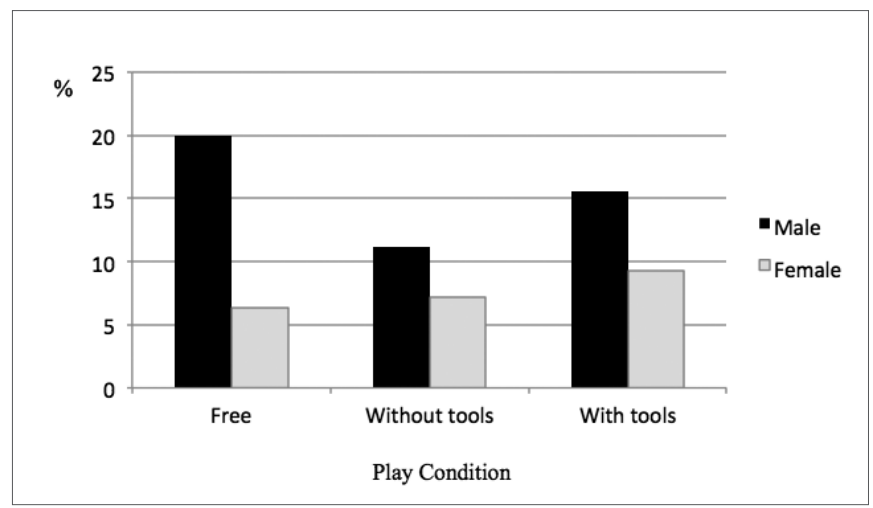

Figure 11. Gender Differences in Rough and Tumble Play.

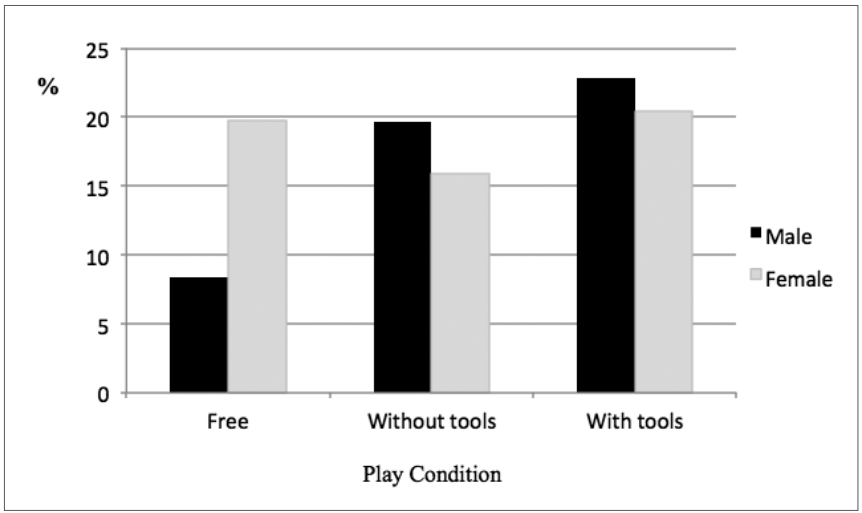

Figure 12. Gender Differences in Dramatic Play.

\section{Teachers' Educational Actions (Figure 13)}

In relation to educational care in conditions of free play, our field work brought us to outline four main typologies of educational care (Figure 13):

1) Participating Presence: the teacher follows children's play constantly, proposing and stimulating children's activity.

2) Discrete Presence: the teacher follows children's play but with a higher active presence, proposing and encouraging but then withdrawing to let the children free.

3) Limitative Attention: the teacher follows the children with the constant concern for preventing dangerous situations, and consequently limits children's spontaneous expression.

4) Detached: the teacher is constantly separate and intervenes only to prevent 
physical dangers or to solve conflicts that might rise among children. The only advantage of this behaviour (which cannot be considered educational care) is that it enables to maximise the manifestation of free play.

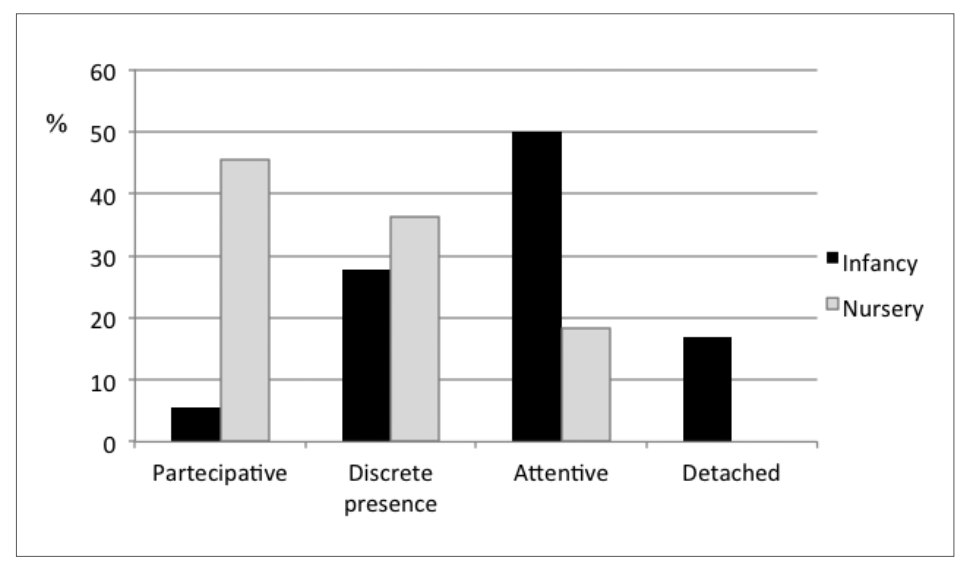

Figure 13. Teacher Behaviours during Children Motor Play in Outdoors.

We can state that there is not a unique typology of educational actions and that all four behaviours described here are needed, even though the present-discrete behaviour should be recommended as best educational action: it engages both teacher and child but leave wide margins of decision to the latter.

\section{Conclusions}

Generally speaking, we can state that there is a significant manifestation of some dominant behaviours in relation to both psycho-motor and socio-motor aspects. Concerning psycho-motor aspects, running, carrying, handling are dominant actions present in various situations of outdoor play. This means that some children's behaviours are also manifested through the use of what the natural environment can offer them, independently from the presence/absence of toys and tools. For instance, if handling is not supported by the presence of tools, children use natural objects (little stick, pebbles, sand) to satisfy their needs. For these behaviours, there are no relevant differences between males and females.

With regard to socio-motor aspects, a similar situation can be observed in which the behaviour constantly links (and this is a fundamental aspect) to group games, to rough-and-tumble play, and to drama play.

Gender differences (which, in fact, are not so relevant among children of this age) are mostly connected to the rough-and-tumble behaviours, prevailing 
among males, and the drama play behaviour, prevailing among females. About the rest, apart from functional play, no relevant gender differences were observed.

We could conclude by stating that changing the conditions of play does not alter the typologies of psycho-motor and socio-motor behaviours that are dominant at this age in a substantial way. Certainly, to modify the educational setting by adding/removing tools increases the manifestation of some behaviour over others; yet, this does not alter the abovementioned balance existing between dominant and accessory behaviours. This confirms the hypothesis that some children's needs are overriding in a situation and are pursued in any case, through adaptation, imagination and creativity. Nevertheless, the educational action can either increase or decrease the manifestation of accessory behaviours through the setting design, as well as through diversified conditions of outdoor play, on the basis of presence/absence of tools and toys.

\section{References}

Bailey, R., Olson, J., Pepper, J., Barstow, T., \& Cooper, D. (1994). The level and tempo of children's physical activities: an observational study. Medicine and Science in Sports and Exercise, 95, 1033-1041. Bandura, A. (1977). Self-efficacy: toward a unifying theory of behavioral change. Psychological Review, $84,191-215$.

Bandura, A. (2001). Social cognitive theory: An agentic perspective. Annual Review of Psychology, 52, $1-26$.

Bateson, G. (1956). The Message 'This Is Play'. New York: Josiah Macy Jr. Foundation.

Bateson, G. (1972). Steps to an ecology of mind. New York: Paladin Book.

Baumgartner, E. (2004). Losservazione del comportamento infantile. Teorie e strumenti. Roma: Carocci.

Bortolotti, A. (2007). Ricerca sul campo di esperienza: 'Corpo, movimento, salute'. In AAVV, Muoversi, giocare, apprendere (pp. 30-53). Bologna: dupress.

Bortolotti, A., \& Ceciliani, A. (2007a). Giocare con cura. Ricerche di Pedagogia e Didattica, 2, 479-525.

Bortolotti, A., \& Ceciliani, A. (2007b). Gioco spontaneo e cure educative. In M. Contini \& M. Manini, $L a$ cura in educazione: tra famiglie e servizi. Roma: Carocci.

Boulton, M. J. (1996). A comparison of 8- and 11-year-old girls' and boys' participation in specific types of rough-and-tumble play and aggressive fighting: implications for functional hypotheses. Aggressive Behavior, 22, 271-287.

Brian, L. (2005). Playground exploration: an Opportunity For Incidental Learning Of Mechanical Principles. Teaching Elementary Physical Education, 16, 21-24.

Burdette, H. L., \& Whitaker, R. C. (2005). Resurrecting Free Play in Young Children. Arch Pediatr Adolesc Med., 159, 46-50.

Caillois, R. (1958). Le jeux et les hommes. La masque et le vertige. Paris: Gallimard. 
Ceciliani, A., Bardella, L., Grasso, ML, Zabonati, A., \& Robazza, C. (2008). Effects of a Physical Education Program on Children's Attitudes and Emotions Associate with Sport Climbing. Perceptual and Motor Skills, 106, 775-784.

Clements, R. (2004). An Investigation of the Status of Outdoor Play. Contemporary Issues in Early

Childhood, 5, 68-82.

Colwell, M. J., \& Lindsey, E. W. (2005). Preschool children's pretend play and physical, and sex of play partner: connection to peer competence. Sex Roles, 52, 497-509.

Contini, M., \& Manini, M. (2007). La cura in educazione: tra famiglie e servizi. Roma: Carocci.

Coplan, R., Wichmann, C., \& Lagace-Seguin, D. (2001). Solitary-active play behavior. A marker variable for maladjustment in the preschool? Journal of Research In Childhood Education, 15, 164-172.

Di Pietro, A. (2003). Ludografie. Bari: La meridiana.

Farné, R. (2005). Pedagogy Of Play. Topoi, 24, 169-181.

Huizinga, J. (1949). Homo Ludens. A study of the play element in culture. London: Routledge (Original Work Published 1939).

Hurwitz, S. C. (2002). To be successful: let them play! Child Education, 79, 101-102.

Kern, P., \& Wakeford, L. (2007). Supporting outdoor play for young children: the zone model of playground. Young Children, 62, 12-18.

Le Camus, J. (1980). Pratiques Psychomotrices. De la RPM aux thérapies a mediàtion corporelle. Bruxelles: Mardaga.

Mc Elwain, E. L., \& Volling, B. L. (2005). Preschool children's interaction with friends and older siblings: relationship specificity and joint contributions to problem behaviours. Journal of Family Psychology, 20, 247-255.

Parlebas, P. (1986). Éléments de Sociologie du Sport. Paris: Puf.

Parlebas, P. (1997). Giochi e Sport. Corpo, comunicazione e creatività ludica. Torino: Il Capitello.

Parten, W. (1932). Social participation among pre-school children. Journal of Abnormal And Social

Psychology, 27, 243-269.

Pellegrini, A. D., \& Smith, P. K. (1998). Physical Activity Play: The Nature and Function of a Neglected Aspect of Play. Child Development, 69, 577-598.

Pellegrini, A. D., \& Smith, P. K. (1998). The development of play during childhood: forms and possible functions. Child Psychology Psychiatry Review, 3, 51-57.

Piaget, J. (1945), La formation du symbole chez l'enfant : imitation, jeu et rêve, image et représentation. Neuchâtel, Paris: Delachaux et Niestlé.

Pica, R. (2003). Your Active Child: how to boost physical, emotional, and cognitive development through age-appropriate activity. Chicago: Contemporary Books.

Rubin, K. H. (2001). The Play Observation Scale (POS). Center for Children, Relationship And Culture, University Of Maryland.

Schilder, P. (1935). Image and Appearance of the Human Body. London: Kegan Paul.

Scott, E., \& Panksepp, J. (2003). Rough-and-Tumble play in human children. Aggressive Behavior, 29,

539-551. 
Sluss, D. G., \&. Stremmler, A. J. (2004). A sociocultural investigation of the effects of peer interaction on play. Journal of Research In Childhood Education, 18, 293-301.

Smith, D. (1995). How play influences children's development at home and school. Journal of Physical Education Recreation Dance, 66, 19-23.

Smith, P. K. (1997). Play fighting and real fighting: perspectives on their relationship. In A. Schmitt, K. Atzwanger, K. Grammer, \& K. Schafer, New Aspects of Ethology. New York: Plenum Press.

Smith, P. K., Smees, R., \& Pellegrini, A. D. (2004). Play fighting and real fighting: using video play back methodology with young children. Aggressive Behaviour, 30, 164-173.

Spray, C. M., \& Wang, C. K. J. (2001). Goal orientations, self-determination and pupils' discipline in physical education. Journal of Sports Sciences, 19, 903-913.

Tsao, L. (2002). How much do we know about the importance of play in child development? Childhood Education, 78, 230-233.

Tucker, P. (2008). The physical activity levels of preschool-aged children: A systematic review. Early Childhood Research Quarterly, 23, 547-558.

Veitch, J., Bagley, S., Ball, K., \& Salmon, J. (2006). Where do children usually play? A qualitative study of parents' perceptions of influences on children's active free-play. Health \& Place, 12, 383-393.

Vygotskij, L. S. (1979). Il gioco e la sua funzione nello sviluppo psichico del bambino. Riforma della Scuola, 7, 41-6o.

Winnicott, D. W. (1971). Playing and Reality. London: Tavistock.

\section{Biographical note}

Alessandro Bortolot ment of Quality for Life, University of Bologna. He currently holds courses in Special Education and Outdoor Education at the Physical Education School and for the Master in Psychomotor Education at the Department of Education. His research are about the area of teaching and learning in sport and health promotion, e.g. Outdoor Education and grassroots sport, particularly for disabled people and in early childhood.

Andrea Ceciliani, Dr., is Assistant Professor at the Department of Quality for Life, University of Bologna. He taught "TTD of the Physical Education for the developmental age" in the school of Exercise and Sport Sciences both in Bologna and Rimini campus. His research field refers to the development of abilities and skills in evolutionary age, with particular attention to the children's play, to prevent posture aspects, and the effects of pedagogical strategies such as Outdoor Education and Learning, Cooperative Learning, Competence or Performance didactics approach on the emotional and motivational aspects. 